\title{
Monitoramento Bacteriológico da Água do Mar e de Sururu (Mytella spp.): Um Estudo Na Ilha do Paty, Baía de Todos Os Santos, Brasil
}

\section{Eleidiana Andréia Seixas de Oliveira (I), Jaqueline Fronza Walker} (I), Palloma de Souza Santos (I), Edilaine Rios Almeida (I), Marcelle Mota de Queiroz (I), Ryzia de Cássia Vieira Cardoso (I), Alaíse Gil Guimarães (I)

(I) UFBA - Universidade Federal da Bahia (Barão de Jeremoabo, 147; Ondiana, Salvador- BA)

\section{Resumo}

A Baía de Todos os Santos - BTS, na Bahia, é considerada a segunda maior baía navegável do mundo e marcada também pela pesca artesanal, com destaque para a mariscagem. A conformidade das áreas de litoral para a mariscagem é influenciada por muitos fatores, mas nenhum é mais vital do que a qualidade da água. O presente estudo objetivou monitorar a qualidade bacteriológica da água do mar e do sururu (Mytella spp.), na Ilha do Paty, BTS, Bahia. Foram avaliadas 30 amostras de água do mar e 12 de sururu, entre dezembro de 2013 e abril de 2014. As primeiras foram coletadas em frascos de vidro estéreis e as últimas em sacos plásticos, procedendo-se transporte resfriado ao laboratório. As amostras de água foram submetidas à pesquisa de coliformes totais, coliformes termotolerantes e Escherichia coli, pela técnica da membrana filtrante, conforme metodologias descritas pelo Standard Methods for the Examination of Water and Wastewater. Para o sururu, foram realizadas a contagem de bactérias aeróbias mesófilas, coliformes a $45^{\circ} \mathrm{C}$, Estafilococos coagulase positiva e pesquisa de Salmonella spp., seguindo-se técnicas da APHA. Na análise da água, as contagens de coliformes totais variaram de 70 a $645 \mathrm{UFC} / 100 \mathrm{~mL}$, enquanto para coliformes termotolerantes e Escherichia coli, os resultados variaram 
entre

Palavras-Chave: água, segurança alimentar, Mytella spp Agência de Fomento: FAPESB 